\title{
Polyethylene Terephthalate Wastes as a Partial Replacement for Fine Aggregates in Concrete Mix, Case of Jimma Town, South West Ethiopia
}

\author{
Temesgen Abeto Amibo ${ }^{1 *}$, Abreham Bekele Bayu ${ }^{1)}$, Desalegn Abdissa Akuma ${ }^{1)}$ \\ ${ }^{1}$ School of Chemical Engineering, Jimma Institute of Technology, Jimma University, Jimma, Ethiopia \\ *Corresponding Authors: temesgen.abeto@ju.edu.et
}

\begin{tabular}{llll}
\multicolumn{1}{c}{ Article history } & & \\
\hline Received & Received in revised form & Accepted & Available online \\
29 December 2020 & 02 February 2021 & 29 March 2021 & 01 April 2021 \\
\hline
\end{tabular}

\begin{abstract}
In this research design of the concrete mix were performed according to the design expert method. The total mixes of 6 and total of 72 samples to consist of concrete grade C-25. The test samples were prepared with the of substitution percentage for the fine aggregate by 1, 2, 3, 4, and 5\% of PET plastic waste aggregate. Moreover, a control mix without replacement for the fine aggregate was used to have a relative analysis. The produced samples consist of concrete cubes, cylinders, and beams. Furthermore, laboratory experiments were carried out for the produced concrete test samples. The experiments conducted were; material property test, slump test, unit weight test, compressive strength test, splitting tensile strength test, and flexural strength test. The test results were investigated and compared with the corresponding conventional concrete characteristics and reflect that there was a slight increase in compressive strength of the concrete up to $3 \%$ replacement and reduction in compressive strength increases beyond 3\% replacement due to the replacement of PET aggregates, also like compressive strength there was an increase of tensile strength obtained with increasing PET bottle aggregate content up to $3 \%$ replacement. But more than 3\% substitution of fine aggregate with PET bottle fiber, results in a reduced in tensile strength, and flexural strength. This test result shows that possible to use PET bottles in concrete production as a partial substitution for fine aggregates not more than 3\% replacement.
\end{abstract}

Keywords; plastic waste, concrete, environmental management, fine aggregate replacement, feasibility

\section{Introduction}

The large quantity of plastic waste generated every year for various activities. Plastics which are used for carrying goods become a waste after use and pollute the environment when it disposed. For example, the use of PET as packaging material for carbonated beverage and water bottles are increased in days to activities [1]. The increase in the use of plastics without recycling is going to yield environmental pollution and as well as many undesirable effects on human health. Plastic wastes are become a serious cause for environmental pollution. In order to manage this environmental problem, the plastic waste bottles (PET) should be recycled or reused [2].

The reuse of PET bottles has many advantages due to its cheap cost. It also contributes to a better environment by recycling PET bottle waste [3]. It is used as an alternative aggregate for concrete in construction industries. Moreover, it leads to open new concrete application areas in the construction industry [4]. It also encourages PET plastic producers to consider PET recycling for income, provides a sustainable market for recycling facilities for a large amount of PET bottles [5]. 
The aim of this research was to investigate the technical feasibility of PET plastic wastes as a partial replacement for fine aggregate in concrete mix for better environmental management. Under this objective the following tasks were performed.

\section{Materials and Methods}

\subsection{The study setting area}

The study was conducted in Jimma City, Oromia National Regional State, and South Ethiopia which was located at $346 \mathrm{Km}$ from Addis Ababa. The total coverage of the city was estimated to be $19,506.24 \mathrm{~m}^{2}$. The climatic condition of the Jimma town constitutes three major climates. It belongs to subtropical, temperate and tropical zones, respectively. Jimma town is a mainly wet season in the period of June to October and the rest was dry season extends from November to May. The maximum temperature of the area is $28^{\circ} \mathrm{Cand}$ the minimum is $12^{\circ} \mathrm{C}$, which occurs in November, where the maximum is in May. In general, rainfall in the area increases with altitude but the pattern is considerably modified by local topography.

\subsection{Study design}

\subsubsection{Material Tests}

The materials like cement, sand, coarse aggregate, and waste PET plastic waste delivered to the laboratory. The PET plastic wastes were washed with water in order to remove impurities before it was grounded. After washing the PET plastic waste, size reduction was done using a cutter machine in the chemical engineering laboratory. The test was done for the input materials to adjust the physical properties of material and suitability, like sieve analysis, silt content of sand, moisture content of aggregate, setting time and consistency of cement.

\subsubsection{Mix Proportioning (Pre-Mix Design)}

A total of 6 mixes with 72 samples for concrete grades of C-25 was produced. It was prepared with fine aggregate replacements by 0 , $1,2,3,4$, and $5 \%$ of the fine PET plastic waste
Those were to check the properties of materials like physical property used for PET plastic waste concrete mix production, to determine hardened or strengthen properties of concrete with and without PET plastic waste, and to optimize the PET plastic waste content in a concrete mix.

aggregate; this was set depending on the previous work of the different researchers. A control mix with no fine PET plastic waste aggregate replacement should be produced to make a comparative analysis which is $0 \%$ replacement.

\subsubsection{Sample preparation and testing}

The test concrete samples were prepared in the Jimma University in a material testing laboratory. The prepared samples have a shape of concrete cubes, cylinders, and beams. Laboratory tests were carried out on the prepared concrete samples. The tests which will be conducted are compressive strength, split tensile strength, and flexural strength. The Schematic flow diagram for the study which is recycling of PET is shown in figure 1 below.

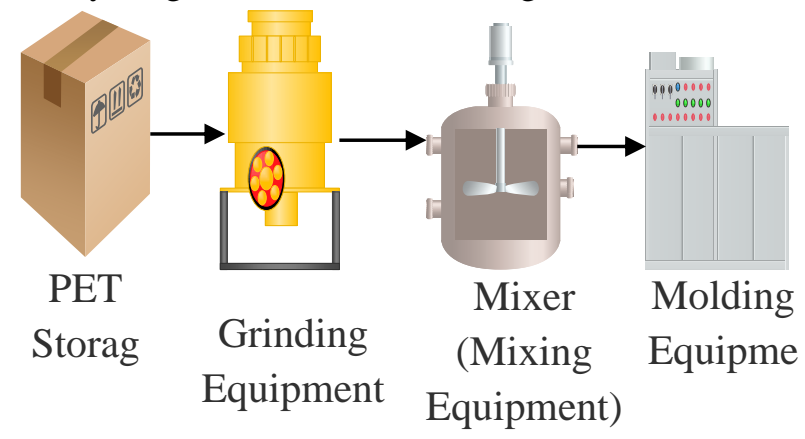

Figure 1. Schematic process flow diagram for the study design

\subsection{Collection of samples}

The collection of raw material includes cement (ordinary Portland cement), fine aggregate from Gambela which is river sand (to the size which ranges from 0.06 up to $2 \mathrm{~mm}$ ), coarse aggregate from Agaro which was $20 \mathrm{~mm}$ size and waste PET plastic wastes (bottles) from Jimma city and JiT which is reduced to the size of $2 \mathrm{~mm}$. The OPC type of cement was used in

http://dx.doi.org/10.22135/sje.2021.6.1.20-35 
this research from the capital manufacturing industry in Ethiopia.

\subsection{Sample preparation}

\subsubsection{Preparation of PET plastic waste}

The PET plastic aggregate was waste plastic bottles that were collected from the local Jimma city and JiT campus. This study was focused on the performance of PET plastic waste which was prepared by manual cutting for shredding and by cutting machine. The minimum size of the PET plastic waste aggregate was river sand size as shown in figure 2. A specific gravity experiment was conducted on the PET plastic waste aggregate chips and found to be 1.05. The PET plastic used in the present investigation were made by manually and using cutting machines.

Figure 2. S $\quad$ S N N / istic waste bottles to river sand size $(2 \mathrm{~mm})$

\subsection{Trial Mixes/Pre Mixes}

The specimens are prepared with a changing amount of PET plastic waste aggregate. The DOE method was used in determining the mix proportions after all

therequired parameters have been obtained a priori. These include the studying physical properties of materials, sieve investigation of aggregates, and their specific gravity. Concrete grades $\mathrm{C}-25$ strength concretes were selected and trial mixes were prepared. Trial mixes were conducted to check the amount of water required or to avoid the use of admixtures [6]. Normal tap water which is free from minerals was used for the test mixes. Subsequent curing was carried out in a curing tank to avoid minor discrepancies from the shortening of the curing period. The specimens were then kept inside the laboratory until the tests were conducted. Parallel to preparing the specimens and conducting the laboratory tests, background study was also conducted in the form of literature reviews so as to correlate the expected results with their actual physical significance. In view of this, a number of textbooks and researches conducted in related areas have been reviewed. Before proceeding to the preparation of the main mix design of the research, trial mixes were prepared for each of the control mixes

Table 1. Material constituents of the trial (pre) mixes

\begin{tabular}{llllll}
\hline $\begin{array}{l}\text { Grade } \\
(\text { Mix ratio })\end{array}$ & $\begin{array}{l}\text { Comp. } \\
\text { strength } \\
(\mathrm{MPa})\end{array}$ & $\begin{array}{l}\text { Cement } \\
\left(\mathrm{kg} / \mathrm{m}^{3}\right)\end{array}$ & $\begin{array}{l}\text { Fine aggregate } \\
\left(\mathrm{kg} / \mathrm{m}^{3}\right)\end{array}$ & $\begin{array}{l}\text { Coarse Aggregate } \\
\left(\mathrm{kg} / \mathrm{m}^{3}\right)\end{array}$ & $\begin{array}{l}\text { Water } \\
(\mathrm{kg})\end{array}$ \\
\hline $\mathrm{C} 25$ & 25 & 346 & 647.02 & 1259.44 & 180 \\
\hline
\end{tabular}

Table 2. Slump and Compressive Strength Test

\begin{tabular}{llcc}
\hline Grade & $\begin{array}{l}\text { Slump } \\
(\mathrm{mm})\end{array}$ & For 7 day & Comp. Strength(MPa) \\
\hline C25 & 12 & 40 & For 28 day \\
\hline
\end{tabular}


The compressive strength tests were conducted at day $7^{\text {th }}$ for the trial mixes.The results were extrapolated to possible at $28^{\text {th }}$-day strength, and the ratio of the $28^{\text {th }}$-day strength to $7^{\text {th }}$-day strength lies between 1.3 and 1.7.It is usually less than 1.5 , depends on the cement type and curing temperature. In other words, the $7^{\text {th }}$-day strength will be on the range between 60 and $75 \%$ of the $28^{\text {th }}$-day strength. For this study, considering the relative early strength development of OPC cement, the maximum value of $75 \%$ of strength achievement at day $7^{\text {th }}$ was assumed to forecast the 28-day strength of the trail mixes. It was found out that the compressive strength test results for the test samples showed a similar trend of the relationship between the seventh and the twenty eight day strengths.

The designed slump was 10-30 $\mathrm{mm}$. Hence, all the slump results are within the Table 3. Mix Proportioning for $1 \mathrm{~m}^{3}$ of Concrete intended range. To proceed for the final preparation of the final mix design, it is mandatory to evaluate the compressive strength test results of the trial mix [7]. The 7th and the estimated 28th-day compressive strength test results revealed that the attained results have exceeded the original intended values. This leads to the understanding that there is still much more adjusting the mix design and a more economical mix can be produced [8]. Based on this, the mix design was readjusted and the final proportioning for the concrete samples was prepared. The designations $\mathrm{Y}$ indicate the concrete grades of 25 compressive strengths. Whereas A1, A2, A3, A4, A5, and A6 indicate the corresponding concrete grades with percentage PET waste plastic aggregate replacements of $0,1,2,3,4$, and $5 \%$ of the fine aggregate respectively.

\begin{tabular}{lllllll}
\hline Type & Grade & $\begin{array}{l}\text { Cement } \\
\left(\mathrm{Kg} / \mathrm{m}^{3}\right)\end{array}$ & $\begin{array}{l}\text { Water } \\
\left(\mathrm{kg} / \mathrm{m}^{3}\right)\end{array}$ & $\begin{array}{l}\text { Fine agg. } \\
\left(\mathrm{kg} / \mathrm{m}^{3}\right)\end{array}$ & $\begin{array}{l}\text { Coarse agg. } \\
\left(\mathrm{kg} / \mathrm{m}^{3}\right)\end{array}$ & $\begin{array}{l}\text { PET agg. } \\
\left(\mathrm{kg} / \mathrm{m}^{3}\right)\end{array}$ \\
\hline Control(YA1) & $\mathrm{C}-25$ & 295 & 180 & 590 & 1180 & 0.00 \\
YA2 & $\mathrm{C}-25$ & 295 & 180 & 590 & 1180 & 5.90 \\
YA3 & $\mathrm{C}-25$ & 295 & 180 & 590 & 1180 & 11.80 \\
YA4 & $\mathrm{C}-25$ & 295 & 180 & 590 & 1180 & 17.70 \\
YA5 & $\mathrm{C}-25$ & 295 & 180 & 590 & 1180 & 23.60 \\
YA6 & $\mathrm{C}-25$ & 295 & 180 & 590 & 1180 & 29.50 \\
\hline
\end{tabular}

In this investigation, a total of 72 mixes consisting of C-25 of concrete samples were produced with partial replacement of the fine aggregate samples by $0,1,2,3,4$, and $5 \%$ of the PET plastic waste aggregate. Moreover, a control mix without substitution of the fine aggregate was prepared to make a comparative investigation which is $0 \%$ replacement. The mix design process adopted was the Department of Environment (DOE) method. The mix content of the basic raw materials like cement, water, and fine aggregate, were the same for the control
However, some amount of the fine aggregate was replaced by an equivalent volume of PET plastic waste aggregate to form PET fiber concrete. Control mix designs, C-25 were prepared for this investigation. The main reason for selecting this concrete grades is that they are known as medium concrete grades [9]. The tests were performed on the different materials and concrete samples produced in this study. These are, slump test, unit weight test, compressive strength test at seventh and twenty eighth day, 
splitting tensile strength test, and flexural strength test.

\subsection{Slump and Unit weight tests}

\subsubsection{Slump tests}

In order to test the workability of the concrete mix, the slump test was done. The slump test is used for determination of either the mix is durable or not.

\subsubsection{Unit weight tests}

The specific gravity of PET plastic wastes unit weight of concrete mix containing PET with the increase in the percentage of fiber Table 4. Mix Proportions for $0.15 \mathrm{~m}^{3}$ of concrete content was evaluated. This measurement was done in the Jimma Institute of Technology civil engineering laboratory.

2.6.3. Compressive, Tensile and Flexural Strength Tests

The strength investigation for compressive, tensile, and flexural had taken for test concrete samples in the Jimma Institute of Technology civil engineering laboratory. For $0.15 \mathrm{~m}^{3}$ capacity mix, the corresponding mix proportioning is shown with Table 4 below.

\begin{tabular}{lllllll}
\hline Type & Grade & $\begin{array}{l}\text { Cement } \\
(\mathrm{Kg} / \mathrm{m} 3)\end{array}$ & $\begin{array}{l}\text { Water } \\
\left(\mathrm{kg} / \mathrm{m}^{3}\right)\end{array}$ & $\begin{array}{l}\text { Fine agg. } \\
\left(\mathrm{kg} / \mathrm{m}^{3}\right)\end{array}$ & $\begin{array}{l}\text { Coarse agg. } \\
\left(\mathrm{kg} / \mathrm{m}^{3}\right)\end{array}$ & $\begin{array}{l}\text { PET agg. } \\
\left(\mathrm{kg} / \mathrm{m}^{3}\right)\end{array}$ \\
\hline Control (YA1) & $\mathrm{C}-25$ & 44.25 & 26.99 & 88.5 & 177.00 & 0 \\
YA2 & $\mathrm{C}-25$ & 44.25 & 26.99 & 88.5 & 177.00 & 1.77 \\
YA3 & $\mathrm{C}-25$ & 44.25 & 26.99 & 88.5 & 177.00 & 3.54 \\
YA4 & $\mathrm{C}-25$ & 44.25 & 26.99 & 88.5 & 177.00 & 5.31 \\
YA5 & $\mathrm{C}-25$ & 44.25 & 26.99 & 88.5 & 177.00 & 7.08 \\
YA6 & $\mathrm{C}-25$ & 44.25 & 26.99 & 88.5 & 177.00 & 8.85 \\
\hline
\end{tabular}

Table 5. Specifications for testing machine

\begin{tabular}{lllll}
\hline S/N & Test machine name & Model No & Capacity & Manufacturer \\
\hline 1 & $\begin{array}{l}\text { compressive and tensile strength } \\
\text { testing machine }\end{array}$ & $\begin{array}{l}\text { ADR 36- } \\
0720 / 01\end{array}$ & $1560 \mathrm{KN}$ & ELE International \\
2 & Flexural test machine & $37-6140$ & $100 \mathrm{KN}$ & ELE International \\
\hline
\end{tabular}

\section{Results and Discussions}

\subsection{Fine Aggregate Physical Properties}

In this research, different materials used for the production of concrete PET were prepared like cement, fine aggregate, coarse aggregate, PET aggregate, and water. The mixtures are with and without PET aggregates for different amounts of PET content [10]. The mixes used in this study were a total of 6 mixes with 72 samples were prepared with concrete grades of C-25, without PET and with PET replacements of the fine aggregate by $1,2,3,4$ and $5 \%$ of the PET aggregate.

3.2. Sieve Analysis

Sieve analysis for fine aggregate was done for the investigation of the fineness modulus of aggregate and the relative amount of various 
Figure 3. The strength tests

sizes of particles present in the aggregate using

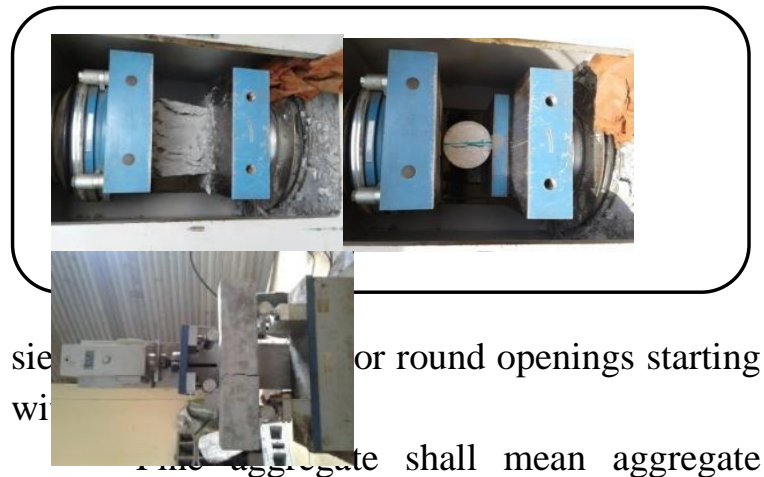

passing $9.5 \mathrm{~mm}$ sieve and almost entirely passing the $4.75 \mathrm{~mm}$ sieve and predominantly retained on the $63 \mu \mathrm{m}$ sieve. The standard fineness modules for fine aggregate are between 2.2 and 2.6and for coarse aggregate, it is in the range of 5.5 to 8.5. The fine aggregates used for this research were washed and dried before the start of the tests. Then followed by sieve analysis table 6 below shows the percentage passing each sieve size and Figure 6 shows the corresponding graph.

Table 6. The percentage passing each sieve size

\begin{tabular}{lllllllll}
\hline $\begin{array}{l}\text { Sieve Size } \\
(\mathrm{mm})\end{array}$ & $\begin{array}{l}\text { Wt. of } \\
\text { Sieve } \\
(\mathrm{gm})\end{array}$ & $\begin{array}{l}\text { Wt.of Sieve and } \\
\text { Retained } \\
(\mathrm{gm})\end{array}$ & $\begin{array}{l}\text { Wt. of } \\
\text { Retained } \\
(\mathrm{gm})\end{array}$ & $\begin{array}{l}\text { Cumul.Wt } \\
\text { Retained } \\
(\mathrm{gm})\end{array}$ & $\begin{array}{c}\text { Cumm. } \\
\% \\
\text { Retained }\end{array}$ & $\begin{array}{l}\% \\
\text { Passing }\end{array}$ & $\begin{array}{l}\text { Lower } \\
\text { Limit }\end{array}$ & $\begin{array}{l}\text { Upp } \\
\text { er } \\
\text { Limi } \\
\text { t }\end{array}$ \\
\hline 9.5 & 585 & 585 & 0 & 0 & 0 & 100 & 100 & 100 \\
4.75 & 566 & 566 & 0 & 0 & 0 & 100 & 95 & 100 \\
2.36 & 522 & 529 & 7 & 7 & 1.4 & 98.6 & 80 & 100 \\
1.18 & 530 & 590 & 60 & 67 & 13.40 & 86.6 & 50 & 90 \\
0.06 & 505 & 685 & 180 & 247 & 49.40 & 50.6 & 25 & 60 \\
0.03 & 476 & 701 & 225 & 472 & 94.40 & 5.6 & 0 & 30 \\
Pan & 422 & 450 & 28 & 500 & 100 & 0 & 0 & 0 \\
Sum & & & 500 & & 258.6 & & & \\
\hline
\end{tabular}

Calculation of fineness modulus according to [19]:

Fineness modulus $=\frac{\Sigma \text { cumulative } \% \text { retained }}{100}$

(1)

Based on equation 1 distribution of fine aggregate showed a good agreement because it is in the range of between 2.2 and 2.6. The corresponding relationship between sieve size and percent passing for fine aggregate is shown in Figure 4.

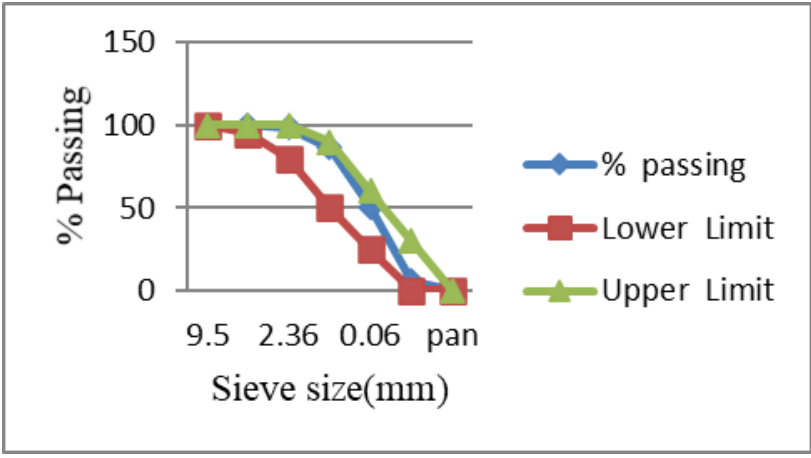

Figure 4. Sieve analysis for fine aggregate.

3.3. Specific gravity and absorption capacity of fine aggregate

The specific gravity of an aggregate is considered to be a measure of strength or quality of the material [12]. The structure of the 
aggregate (size, number, and continuity pattern) affects water absorption, permeability, and Table 7. Specific gravity and absorption capacity of fine aggregate test results

\begin{tabular}{cll}
\hline No. & Description & Test Results \\
\hline 1 & Bulk Specific gravity & 2.41 \\
2 & Bulk Specific gravity (SSD basis) & 2.51 \\
3 & Apparent specific gravity & 2.68 \\
4 & Absorption capacity & $4.16 \%$ \\
5 & Moisture content & $2.66 \%$ \\
\hline
\end{tabular}

\subsection{Moisture content of fine aggregate}

The wet aggregates give water to the mix and drier aggregates take water from the mix affecting in cases, the design water-cement ratio, and therefore workability and strength of the mix. The moisture content of the fine aggregate sample used for this study was around $2.4 \%$.

\subsection{Silt content of fine aggregate}

From the silt content test performed on the sand, it was found that the original silt content was $9 \%$. Therefore, it was necessary to wash the sand to improve the property. Finally, specific gravity. The following table 7 shows the results found for the fine aggregate sample. the silt content reached $3 \%$ that is within the acceptable range.

\subsection{Properties of the coarse aggregate}

Laboratory tests were carried out to identify the physical properties of the coarse aggregate and to investigate its properties and suitability for the intended application [20]. The following tests were carried out. These were percentage of moisture content, unit weight of coarse aggregate, bulk specific gravity, bulk specific gravity (SSD basis), apparent specific gravity, absorption capacity, crushing value of aggregate, and Los Angeles abrasion test.

Table 8. Physical properties of coarse aggregate and results

\begin{tabular}{lll}
\hline No. & Description & Test Results \\
\hline 1 & Bulk Specific gravity & 2.78 \\
2 & Bulk specific gravity(SSD basis) & 2.90 \\
3 & Apparent specific gravity & 2.93 \\
4 & Absorption capacity & $1.39 \%$ \\
5 & Moisture content & $1.31 \%$ \\
6 & Unit weight of coarse aggregate & $1.542 \mathrm{~g} / \mathrm{cm}^{3}$ \\
7 & Crushing value of aggregate & $18.05 \%$ \\
8 & Los Angeles Abrasion Test & $14.72 \%$ \\
\hline
\end{tabular}


Table 9. Sieve Analysis for the Coarse Aggregate.

\begin{tabular}{lllllllll}
\hline $\begin{array}{l}\text { Sieve Size } \\
(\mathrm{mm})\end{array}$ & $\begin{array}{l}\text { Wt. of } \\
\text { Sieve } \\
(\mathrm{gm})\end{array}$ & $\begin{array}{l}\text { Wt.ofSieve } \\
\text { and Retained } \\
(\mathrm{gm})\end{array}$ & $\begin{array}{l}\text { Wt. of } \\
\text { Retained } \\
(\mathrm{gm})\end{array}$ & $\begin{array}{l}\text { Cumu.Wt } \\
\text { Retained } \\
(\mathrm{gm})\end{array}$ & $\begin{array}{l}\text { Cumul. } \\
\% \\
\text { Retained }\end{array}$ & $\begin{array}{l}\% \\
\text { Passing }\end{array}$ & $\begin{array}{l}\text { Lower } \\
\text { Limit }\end{array}$ & $\begin{array}{l}\text { Upper } \\
\text { Limit }\end{array}$ \\
\hline 37.5 & 1187 & 1187 & 0 & 0 & 0 & 100 & 100 & 100 \\
19 & 1420 & 1420 & 0 & 0 & 0 & 100 & 90 & 100 \\
13.2 & 1166 & 4144 & 2978 & 2978 & 45.70 & 54.30 & 40 & 80 \\
9.5 & 1171 & 3180 & 2009 & 4987 & 76.53 & 23.47 & 10 & 50 \\
4.75 & 1195 & 2724 & 1529 & 6516 & 100 & 0 & 0 & 10 \\
2.36 & 1080 & 1080 & 0 & 6516 & 100 & 0 & 0 & 10 \\
1.18 & 1102 & 1102 & 0 & 6516 & 100 & 0 & 0 & 10 \\
0.6 & 1098 & 1098 & 0 & 6516 & 100 & 0 & 0 & 10 \\
Pan & 1060 & 1060 & 0 & 6516 & 100 & 0 & 0 & 10 \\
Sum & & & 6516 & & 622.23 & & & \\
\hline
\end{tabular}

The sieve analysis is showed on table 9 .

Based on equation 1, the distribution of coarse aggregate is well because it is in the range between 5.5 and 8 . The corresponding relationship between Sieve size and percent passing for coarse aggregate is shown on Figure 5.

Table 10. Test results found for fine aggregate

\begin{tabular}{lll}
\hline No. & Description & Test Results \\
\hline 1 & Bulk Specific gravity & 2.41 \\
2 & Bulk Specific gravity (SSD basis) & 2.51 \\
3 & Apparent specific gravity & 2.68 \\
4 & Absorption capacity & $4.16 \%$ \\
\hline
\end{tabular}

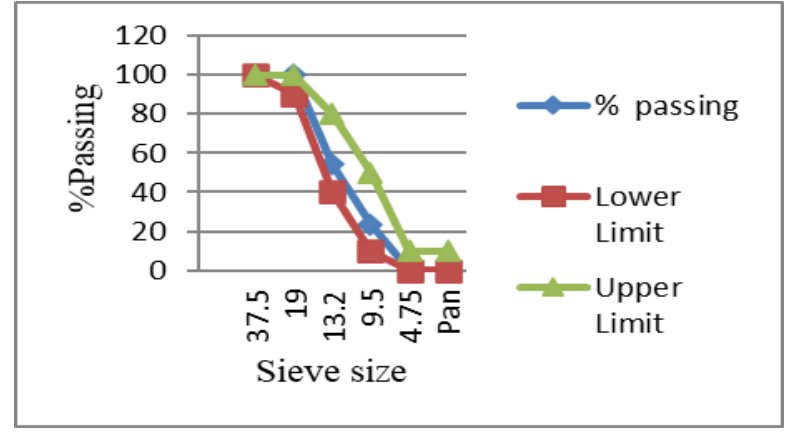

Figure 5. Sieve analysis of coarse aggregate

\subsection{Aggregate test results}

Aggregates should clean from the impurities like silt, clay, dirt, or organic matter. If these materials coat the surfaces of the aggregate, It would isolate the aggregate particles from the surrounding concrete to proportion suitable concrete mixes, certain properties of the aggregate must be known. The test result for fine aggregate and coarse aggregates shown with the following $\mathrm{tTable} 10$ and Table 11, respectively.

Table 11. Test results found for coarse aggregate

\begin{tabular}{lll}
\hline No & Description & Test \\
\hline 1 & Bulk Specific gravity & 2.82 \\
2 & Bulk specific gravity(SSD basis) & 2.85 \\
3 & Apparent specific gravity & 2.93 \\
4 & Absorption capacity & $1.39 \%$ \\
5 & Moisture content & $1.31 \%$ \\
7 & Crushing value of aggregate & $18.05 \%$ \\
8 & Los Angeles Abrasion Test & $14.72 \%$ \\
\hline
\end{tabular}




\subsection{Fresh Properties of concrete test results}

\subsubsection{Workability Test result}

In the slump test, the distance that a cone full of concrete slumps down is measured when the cone is lifted from around the concrete [14]. As observed in Table 17, the slump and workability increased as a percentage of PET increased with the same water-cement ratio. All the test results show that the slumps are between the designed ranges $(10-30 \mathrm{~mm})$. In general, PET plastic waste concrete mixes did not show any problems in terms of finishing, casting and substitution can be finished into the similar standard as plain concrete. The slump test and results were listed in the table below table 12 .

Table 12. Slump Test Results

\begin{tabular}{llllll}
\hline S/N & Samples & Grade & \%PET & w/c ratio & Slump $(\mathrm{mm})$ \\
\hline 1 & YA1 & C-25 & 0 & 0.52 & 13 \\
2 & YA2 & C-25 & 1 & 0.52 & 15 \\
3 & YA3 & C-25 & 2 & 0.52 & 18 \\
4 & YA4 & C-25 & 3 & 0.52 & 24 \\
5 & YA5 & C-25 & 4 & 0.52 & 27 \\
6 & YA6 & C-25 & 5 & 0.52 & 29 \\
\hline
\end{tabular}

\subsubsection{Hardened Properties of Concrete results}

The Strengthen properties of the concrete samples prepared were tested for different properties, including determination of unit weight, compressive strength, splitting tensile strength, and flexural strength tests [15].

\subsubsection{Unit weight Determination}

The decrease in the unit weight of PET concrete is negligible when PET content is lower than 1 to $3 \%$ of the total aggregate volume. The unit weight values used for the analysis of this section were measured from the concrete cube samples after 28 days of standard curing. From the results, it was found out that a reduction of unit weight 3.92, 9.01, 20.78, 22.35 and $26.66 \%$ was observed when $1 \%, 2 \%, 3 \%, 4 \%$ and $5 \%$ by volume of the fine aggregate was replaced by PET plastic waste aggregate in sample YA2, YA3, YA4, YA5, and YA6 respectively. As the laboratory result shows table 18 specific gravity of the PET plastic waste aggregate is lower than that of fine aggregates, this leads to the reduction of unit weight. Because of the PET fiber aggregate is lighter than around two and half times of fine aggregate, it was expected that the mass density of the mix would be suggestively reduced.

The unit weight determination for the first seven-week and for the next 4 weeks is shown with the following table 13 and 14 respectively. The unit weight determination for 28 days is shown in table 14

\subsubsection{Compressive strength Test}

The experiment was carried out to investigate the compressive strengths of concrete specimens the 7th and 28th days of standard curing. The test results show that the addition of PET aggregate resulted in an appreciable increase in the compressive strength is observed up to $3 \%$ substitution of the fine aggregate with PET bottle fibers and the compressive strength is gradually decreased compared with the control concrete. An increase in compressive strength of $13.16 \%$ (YA2) was observed when $1 \%$ of the fine aggregate was replaced by an equivalent volume of PET plastic waste aggregate. An increase of compressive strength $15.58 \%$ (YA3) was observed when $2 \%$ of fine aggregate was replaced by PET aggregate.

The observed increments of strength when $3 \%$ of the fine aggregate was replaced by 
PET aggregate were $21.53 \%$ (YA4). Losses of $9.22 \%$ (YA5) were observed when $4 \%$ of fine aggregate was replaced by PET aggregate. Finally, losses of strength $2.73 \%$ (YA6) were Table 13. A7 day unit weight determination

\begin{tabular}{|c|c|c|c|c|c|c|c|}
\hline $\mathrm{NO}$ & $\begin{array}{l}\text { Specime } \\
\mathrm{n}\end{array}$ & Sample No. & Grade & $\%$ PET & $\begin{array}{l}\text { Samples } \\
\text { Unit } \\
\text { wt. }\left(\mathrm{gm} / \mathrm{cm}^{3}\right)\end{array}$ & $\begin{array}{l}\text { Average } \\
\text { Unit wt. }\left(\mathrm{gm} . / \mathrm{cm}^{3}\right)\end{array}$ & $\begin{array}{l}\text { \%Reductio } \\
\mathrm{n}\end{array}$ \\
\hline 1 & YA1 & $\begin{array}{l}1 \\
2 \\
3\end{array}$ & $\mathrm{C}-25$ & 0 & $\begin{array}{l}2.53 \\
2.53 \\
2.57\end{array}$ & 2.54 & 0.00 \\
\hline 2 & YA2 & $\begin{array}{l}1 \\
2 \\
3\end{array}$ & $\mathrm{C}-25$ & 1 & $\begin{array}{l}2.42 \\
2.45 \\
2.56\end{array}$ & 2.48 & 2.36 \\
\hline 3 & YA3 & $\begin{array}{l}1 \\
2 \\
3\end{array}$ & $\mathrm{C}-25$ & 2 & $\begin{array}{l}2.24 \\
2.30 \\
2.27\end{array}$ & 2.27 & 10.62 \\
\hline 4 & YA4 & $\begin{array}{l}1 \\
2 \\
3\end{array}$ & $\mathrm{C}-25$ & 3 & $\begin{array}{l}2.18 \\
2.12 \\
2.15\end{array}$ & 2.15 & 15.35 \\
\hline 5 & YA5 & $\begin{array}{l}1 \\
2 \\
3\end{array}$ & $\mathrm{C}-25$ & 4 & $\begin{array}{l}2.15 \\
2.09 \\
2.12\end{array}$ & 2.12 & 16.53 \\
\hline 6 & YA6 & $\begin{array}{l}1 \\
2 \\
3 \\
\end{array}$ & $\mathrm{C}-25$ & 5 & $\begin{array}{l}2.12 \\
2.06 \\
2.09 \\
\end{array}$ & 2.09 & 17.71 \\
\hline $\mathrm{NO}$ & Specimen & Sample No. & Grade & $\begin{array}{l}\% \\
\text { PET }\end{array}$ & $\begin{array}{l}\text { Samples } \\
\text { Unit } \\
\text { wt. }\left(\mathrm{gm} / \mathrm{cm}^{3}\right)\end{array}$ & $\begin{array}{l}\text { Average } \\
\text { Unit wt. }\left(\mathrm{gm} . / \mathrm{cm}^{3}\right)\end{array}$ & \%Reduction \\
\hline 1 & YA1 & $\begin{array}{l}1 \\
2 \\
3\end{array}$ & $\mathrm{C}-25$ & 0 & $\begin{array}{l}2.59 \\
2.54 \\
2.53\end{array}$ & 2.55 & 0.00 \\
\hline 2 & YA2 & $\begin{array}{l}1 \\
2 \\
3\end{array}$ & $\mathrm{C}-25$ & 1 & $\begin{array}{l}2.45 \\
2.41 \\
2.48\end{array}$ & 2.45 & 3.92 \\
\hline 3 & YA3 & $\begin{array}{l}1 \\
2 \\
3\end{array}$ & $\mathrm{C}-25$ & 2 & $\begin{array}{l}2.28 \\
2.38 \\
2.29\end{array}$ & 2.32 & 9.01 \\
\hline 4 & YA4 & $\begin{array}{l}1 \\
2 \\
3\end{array}$ & $\mathrm{C}-25$ & 3 & $\begin{array}{l}1.98 \\
2.09 \\
1.99\end{array}$ & 2.02 & 20.78 \\
\hline 5 & YA5 & $\begin{array}{l}1 \\
2 \\
3\end{array}$ & $\mathrm{C}-25$ & 4 & $\begin{array}{l}1.98 \\
2.01 \\
1.95\end{array}$ & 1.98 & 22.35 \\
\hline 6 & YA6 & $\begin{array}{l}1 \\
2 \\
3\end{array}$ & $\mathrm{C}-25$ & 5 & $\begin{array}{l}1.87 \\
1.85 \\
1.89\end{array}$ & 1.87 & 26.66 \\
\hline
\end{tabular}

observed for PET concrete containing 5\% by volume of PET aggregate replacement. Table 15 and Table 16 below show the results of the $7^{\text {th }}$ and $28^{\text {th }}$-day compressive strength tests. 
Table 15. Compressive strength test results for 7 days.

\begin{tabular}{|c|c|c|c|c|c|c|c|}
\hline \multirow[t]{2}{*}{ No. } & \multirow[t]{2}{*}{ Samples } & \multirow{2}{*}{$\begin{array}{lr}\text { No. } & \text { of } \\
\text { Samples } & \text { per } \\
\text { test }\end{array}$} & \multirow[t]{2}{*}{ Grade } & \multirow[t]{2}{*}{$\%$ PET } & \multirow{2}{*}{$\begin{array}{l}\text { Individual samples } \\
\text { Comp.str(MPa) }\end{array}$} & Comp.str. (MPa) & \multirow{2}{*}{$\begin{array}{l}\text { \%Str.Increment } \\
\& \text { loss }\end{array}$} \\
\hline & & & & & & $\begin{array}{ll}\text { (Average) } & 7 \\
\text { Days } & \end{array}$ & \\
\hline \multirow[t]{3}{*}{1} & YA1 & 1 & $\mathrm{C}-25$ & 0 & 23.30 & 22.60 & 0.00 \\
\hline & & 2 & & & 22.20 & & \\
\hline & & 3 & & & 21.10 & & \\
\hline \multirow[t]{3}{*}{2} & YA2 & 1 & C-25 & 1 & 26.02 & 25.03 & 10.75 \\
\hline & & 2 & & & 24.01 & & \\
\hline & & 3 & & & 25.07 & & \\
\hline \multirow[t]{3}{*}{3} & YA3 & 1 & $\mathrm{C}-25$ & 2 & 28.04 & 27.05 & 19.69 \\
\hline & & 2 & & & 27.03 & & \\
\hline & & 3 & & & 26.07 & & \\
\hline \multirow[t]{3}{*}{4} & YA4 & 1 & C-25 & 3 & 28.40 & 28.00 & 23.89 \\
\hline & & 2 & & & 28.50 & & \\
\hline & & 3 & & & 27.10 & & \\
\hline \multirow[t]{3}{*}{5} & YA5 & 1 & C- -25 & 4 & 26.30 & 25.23 & 11.63 \\
\hline & & 2 & & & 24.10 & & \\
\hline & & 3 & & & 25.10 & & \\
\hline \multirow[t]{3}{*}{6} & YA6 & 1 & $\mathrm{C}-25$ & 5 & 23.02 & 23.04 & 1.94 \\
\hline & & 2 & & & 24.04 & & \\
\hline & & 3 & & & 22.05 & & \\
\hline
\end{tabular}

Table 16. Compressive strength test results for 28 days.

\begin{tabular}{|c|c|c|c|c|c|c|c|}
\hline \multirow[t]{2}{*}{ No } & \multirow[t]{2}{*}{ Samples } & \multirow{2}{*}{$\begin{array}{l}\text { No. of Samples } \\
\text { per test }\end{array}$} & \multirow[t]{2}{*}{ Grade } & \multirow[t]{2}{*}{$\%$ PET } & \multirow{2}{*}{$\begin{array}{l}\text { Individual samples } \\
\text { Comp.str(MPa) }\end{array}$} & \multicolumn{2}{|l|}{ Comp.str. (MPa) } \\
\hline & & & & & & $\begin{array}{l}\text { (Average) } \\
\text { Days }\end{array}$ & $\begin{array}{l}\% \text { Str.Incre } \\
\text { ment \& } \\
\text { loss }\end{array}$ \\
\hline \multirow[t]{3}{*}{1} & YA1 & 1 & $\mathrm{C}-25$ & 0 & 32.40 & 31.44 & 0.00 \\
\hline & & 2 & & & 30.50 & & \\
\hline & & 3 & & & 31.43 & & \\
\hline \multirow[t]{3}{*}{2} & YA2 & 1 & $\mathrm{C}-25$ & 1 & 35.90 & & 13.16 \\
\hline & & 2 & & & 36.30 & 35.58 & \\
\hline & & 3 & & & 34.55 & & \\
\hline \multirow[t]{3}{*}{3} & YA3 & 1 & $\mathrm{C}-25$ & 2 & 36.30 & 36.34 & 15.58 \\
\hline & & 2 & & & 37.42 & & \\
\hline & & 3 & & & 35.29 & & \\
\hline \multirow[t]{3}{*}{4} & YA4 & 1 & $\mathrm{C}-25$ & 3 & 38.32 & 38.21 & 21.53 \\
\hline & & 2 & & & 39.10 & & \\
\hline & & 3 & & & 37.21 & & \\
\hline \multirow[t]{3}{*}{5} & YA5 & 1 & $\mathrm{C}-25$ & 4 & 35.22 & 34.34 & 9.22 \\
\hline & & 2 & & & 34.37 & & \\
\hline & & 3 & & & 33.43 & & \\
\hline \multirow[t]{3}{*}{6} & YA6 & 1 & $\mathrm{C}-25$ & 5 & 33.40 & 32.30 & 2.73 \\
\hline & & 2 & & & 32.01 & & \\
\hline & & 3 & & & 31.50 & & \\
\hline
\end{tabular}


Table 17. Splitting Tensile Strength Test Results

\begin{tabular}{|c|c|c|c|c|c|c|c|c|}
\hline No. & Samples & $\begin{array}{l}\text { No. of } \\
\text { samples } \\
\text { per test }\end{array}$ & Grade & $\%$ PET & $\begin{array}{l}\text { Splitting } \\
\operatorname{Load}(k N)\end{array}$ & $\begin{array}{l}\text { Individual } \\
\text { splitting } \\
\text { strength(MPa) }\end{array}$ & $\begin{array}{l}\text { Splitting } \\
\text { Streng.(MPa) } \\
\text { (Average) }\end{array}$ & $\begin{array}{l}\% \\
\text { Streng. } \\
\& \text { loss }\end{array}$ \\
\hline \multirow[t]{3}{*}{1} & YA1 & 1 & & 0 & 61.20 & 1.95 & 1.90 & 0.00 \\
\hline & & 2 & C-25 & & 59.60 & 1.90 & & \\
\hline & & 3 & & & 58.00 & 1.85 & & \\
\hline \multirow[t]{3}{*}{2} & YA2 & 1 & & 1 & 64.30 & 2.05 & 2.12 & 11.57 \\
\hline & & 2 & & & 67.80 & 2.16 & & \\
\hline & & 3 & & & 67.50 & 2.15 & & \\
\hline \multirow[t]{3}{*}{3} & YA3 & 1 & & 2 & 68.40 & 2.18 & 2.17 & 14.2 \\
\hline & & 2 & & & 67.80 & 2.16 & & \\
\hline & & 3 & & & 68.10 & 2.17 & & \\
\hline \multirow[t]{3}{*}{4} & YA4 & 1 & & 3 & 70.00 & 2.23 & 2.22 & 1.68 \\
\hline & & 2 & & & 69.00 & 2.20 & & \\
\hline & & 3 & & & 70.00 & 2.23 & & \\
\hline \multirow[t]{3}{*}{5} & YA5 & 1 & & 4 & 67.50 & 2.15 & 2.10 & 10.52 \\
\hline & & 2 & & & 64.30 & 2.05 & & \\
\hline & & 3 & & & 65.90 & 2.10 & & \\
\hline \multirow[t]{3}{*}{6} & YA6 & 1 & & 5 & 64.30 & 2.05 & 2.04 & 7.36 \\
\hline & & 2 & & & 63.70 & 2.03 & & \\
\hline & & 3 & & & 64.00 & 2.04 & & \\
\hline
\end{tabular}

The 28 days the compressive strength test result is shown with the following table (Table 16). Figure 6 below shows the strength of the concrete sample prepared and the comparison of the strength achieved in contrast with the control concrete for 7 and 28-day result.

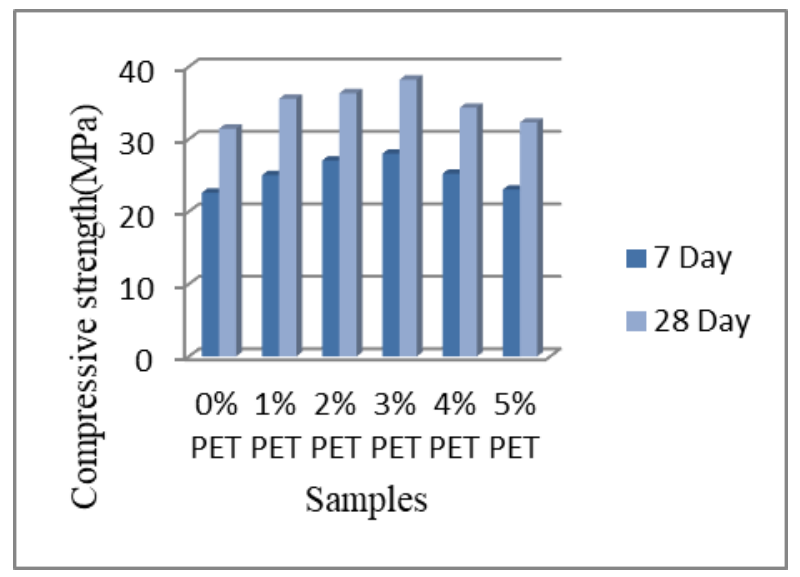

Figure 6. Compressive strength comparisons of samples.

As observed from the above experiment results, there was a significant reduction of

Vol. 6 No. 1, 20-35 compressive strength as a percentage of PET increased beyond 3\% substitution of fine aggregates with PET aggregate.

The cause for the compressive strength significant reductions could be both to a lack of the quantity of the solid load-carrying material and to the lack of adhesion at the surfaces of the PET aggregate. PET fiber particles favor voids in the concrete matrix. PET has a very low modulus of elasticity of about $6.5 \mathrm{MPa}$ and a Poisson's ratio of 0.5 . Therefore, PET aggregates show to behave like voids in the concrete, resulting in a lowering in compressive strength. It is well known that the presence of voids in concrete greatly reduces its strength.

\subsubsection{Split tensile strength Test}

The splitting tensile strength test is an indirect tension test for concrete. It is carried out on a standard cylinder, tested on its side in diametric compression [16]. The load is usually applied through narrow bearing strips of relatively soft material. The split tensile strength of the cylinder sample was determined by using 
the following formula is splitting tensile strength test result is shown in table 17 below. The Split Tensile Strength can be calculated by using equation.

$$
\mathrm{fsp}=2 \mathrm{p} / \pi \mathrm{ld}
$$

Where, $\mathrm{P}$ is load at failure in $\mathrm{N}, \mathrm{L}$ is the length of the Specimen in $\mathrm{mm}$, and $\mathrm{d}$ is the diameter of the Specimen in $\mathrm{mm}$.

The experiment results showed that the splitting tensile strength increased with increasing PET bottle aggregate content in a similar manner to that observed in the compressive strength tests up to $3 \%$ replacement. The increases of strength up to $11.57 \%$ (YA2) when $1 \%$ of the fine aggregate was replaced by PET bottle aggregate. Increases of up to $14.2 \%$ (YA3) observed when $2 \%$ of the fine aggregate was replaced by PET bottle aggregate. The increase of strength $1.68 \%$ (YA4) observed when $3 \%$ of fine aggregate replaced by PET bottle aggregate. The observed losses of strength when $4 \%$ of fine aggregate was replaced by PET bottle aggregate were $10.52 \%$ (YA5). When a5\% volume of the fine aggregate was replaced by PET aggregate, it losses of $7.36 \%$ (YA6). The comparison is shown on Figure 7.

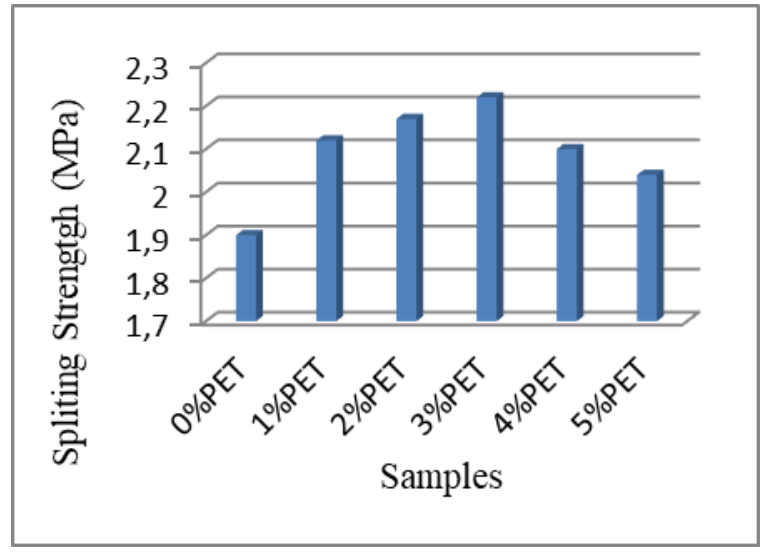

Figure 7. Comparisons of splitting tensile strength test results

One of the reasons that splitting tensile strength of the PET bottle concrete is lower than

Vol. 6 No. 1, 20-35 the standard concrete beyond 3\% replacement is that bond strength between cement paste and PET bottle particles is poor.

3.6.6. Flexural strength Tests

This experiment test gives another direction of estimating the tensile strength of concrete. During pure bending, the member resisting the action is subjected to internal actions or stresses like shear, tensile, and compressive.

For this load and support system, portions of the member near the supports are subjected to relatively higher shear stresses than tensile stresses according to [17]. In this test, the concrete member to be tested is supported at its ends and loaded at its interior locations by a gradually increasing load to failure. The failure load (loading value at which the concrete cracks heavily) is then recorded and used to determine the tensile stress at which the member failed, i.e. its tensile strength. The prepared beam samples were tested after 28 days of standard curing and the results of flexural strength tests for the control concretes and the PET bottle concretes are summarized below in Table 23. The flexural strength of the prism specimen is calculated using the following formula according to [18].

$\mathrm{C}=\frac{\mathrm{D}}{2} \mathrm{~cm}$

$\mathrm{M}=\frac{\mathrm{PL}}{3} \mathrm{~N} . \mathrm{m}$

$\mathrm{I}=\frac{\mathrm{BD}^{\mathrm{s}}}{12} \mathrm{~m}^{4}$

$\sigma=\frac{\mathrm{MC}}{\mathrm{I}} \mathrm{MPa}$

Where: $\mathrm{P}$ is failure load, $\sigma$ is bending strength, $\mathrm{M}$ is maximum moment, $\mathrm{L}$ is Span of specimen, $\mathrm{I}$ is moment of inertia, $\mathrm{D}$ is depth of specimen, $\mathrm{C}$ is centroid depth, $\mathrm{B}$ is width of the specimen.

Equation (3) to (6) was used to determine each factor. Comparing this result with the control one from table 18 there was an increased flexural strength up to three percent $(3 \%)$ of the fine aggregate was replaced by PET bottle aggregate but becomes reduced of flexural 
strength observed when more than three percent (3\%) of fine aggregate replaced by PET bottle aggregate compared with control. This implies that improvements in flexural strength are limited to a relatively small amount of PET aggregate contents. As the test result shows there was an advantage of increasing flexural strength to some extent replacing fine aggregate by $3 \%$ of PET bottle aggregate.

It can be concluded that as the amount of PET bottle fiber content increases, by more than $3 \%$ the reduction in the flexural strength also increases. Comparisons of flexural strength test results are shown Figure 8.

Table 18. Flexural strength tests results

\begin{tabular}{|c|c|c|c|c|c|c|c|}
\hline No. & Samples & $\begin{array}{l}\text { No. of } \\
\text { samples } \\
\text { per test }\end{array}$ & Grade & $\%$ PET & $\begin{array}{l}\text { Fluxeral Streng of } \\
\text { Samples }(\mathrm{MPa})\end{array}$ & $\begin{array}{l}\text { Average } \\
\text { Fluxeral Streng of } \\
\text { Samples(MPa) }\end{array}$ & $\begin{array}{l}\text { \% Streng. } \\
\text { increase\&loss }\end{array}$ \\
\hline \multirow[t]{3}{*}{1} & YA1 & 1 & & 0 & 3.06 & 3.05 & 0.00 \\
\hline & & 2 & $\mathrm{C}-25$ & & 3.04 & & \\
\hline & & 3 & & & 3.05 & & \\
\hline \multirow[t]{3}{*}{2} & YA2 & 1 & & 1 & 4.98 & 4.93 & 61.63 \\
\hline & & 2 & & & 4.87 & & \\
\hline & & 3 & & & 4.95 & & \\
\hline \multirow[t]{3}{*}{3} & YA3 & 1 & & 2 & 5.80 & 5.85 & 91.80 \\
\hline & & 2 & & & 5.85 & & \\
\hline & & 3 & & & 5.90 & & \\
\hline \multirow[t]{3}{*}{4} & YA4 & 1 & & 3 & 6.00 & 6.05 & 98.36 \\
\hline & & 2 & & & 6.10 & & \\
\hline & & 3 & & & 6.05 & & \\
\hline \multirow[t]{3}{*}{5} & YA5 & 1 & & 4 & 5.91 & 5.88 & 92.78 \\
\hline & & 2 & & & 5.72 & & \\
\hline & & 3 & & & 5.80 & & \\
\hline \multirow[t]{3}{*}{6} & YA6 & 1 & & 5 & 5.79 & 5.80 & 90.16 \\
\hline & & 2 & & & 5.82 & & \\
\hline & & 3 & & & 5.81 & & \\
\hline
\end{tabular}

Figure 8. Comparisons of Flexural strength test results

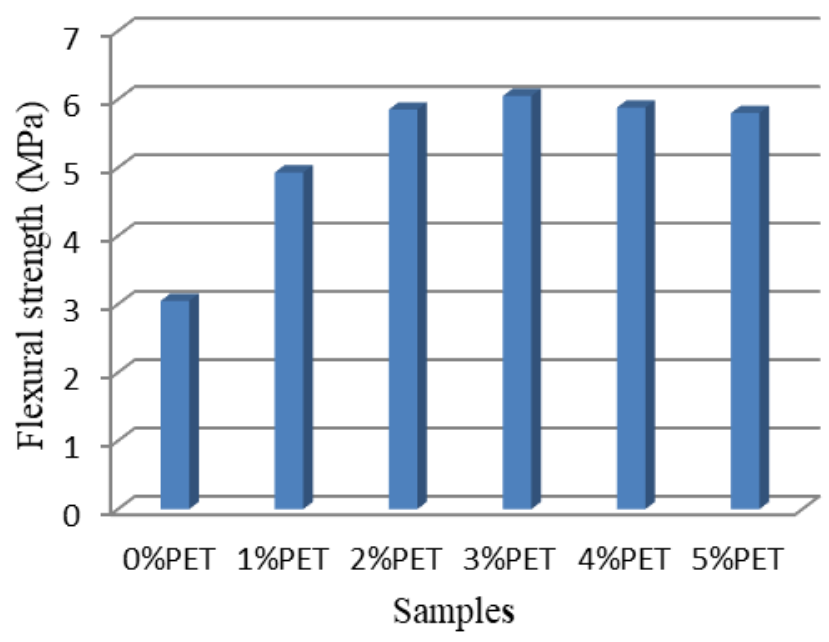

\section{Conclusions}

The test results indicate that the addition of PET bottle aggregate resulted in a substantial increase in concrete compressive strength up to $3 \%$ partial substitution of fine aggregate with PET bottle aggregate compared with the control concrete. As observed from the experimental test

Vol. 6 No. 1, 20-35 results there was a reduction of strength as a percentage of PET increased beyond 3\%. The compressive strength was slightly increased with tensile strength as recorded with increasing PET bottle aggregate content up to $3 \%$ replacement. But more than $3 \%$ replacement of fine aggregate with PET bottle fiber results in a reduction in http://dx.doi.org/10.22135/sje.2021.6.1.20-35 33 
tensile strength. Because of the bond between cement paste and PET bottle fiber particles is poor. Increased flexural strength was observed by replacing the amount of PET bottle fiber with fine aggregate up to three percent (3\%) used. But when the percentage of PET bottle fiber increased more than three percent $(3 \%)$ flexural strength increases and starts to decline were observed. It can be concluded that as the amount of PET bottle fiber content increases, the reduction in the flexural strength also increases. The advantage of using PET bottle fiber aggregates from waste plastic are; reduction of the environmental problems caused by waste plastic bottles, an alternative source to aggregates and reduces bio disturbance caused by during quarry of aggregates. There was an advantage of increasing flexural strength to some extent replacing fine aggregate by $3 \%$ of PET bottle fiber aggregate only. It can be concluded that as the amount of PET bottle fiber content increases, by more than $3 \%$ the reduction in the flexural strength also increases.

\section{Acknowledgment}

This research work would not have been feasible without the sincere cooperation and support of the organizations and individuals who have provided us with all the relevant information and data. These are Jimma University Chemical Engineering Laboratory, Jimma University Civil, and Environmental Engineering Laboratory.

\section{References}

[1] M.J.Kirwan, S.Plant, and J.W.Strawbridge. "Plastics in Food Packaging".Food and beverage packaging technology. pp.157-212. 2011. ISBN: 978-1-444-39217-3.

[2] H.Tanyildizi. "Statistical Analysis For Mechanical Properties Of Polypropylene Fiber Reinforced Lightweight Concrete Containing Silica Fume Exposed To High

Vol. 6 No. 1, 20-35
Temperature". Materials\&Design, 30(8).200 9. pp.3252-3258.

[3] G. Pachideh, and M. Gholhaki, M. "Using Steel And Polypropylene Fibres To Improve The Performance Of Concrete Sleepers". Proceedings of the Institution of Civil Engineers-Structures and Buildings. 2019. pp.1-38.

[4] J. D. Brito, and N. Saikia. "Recycled Aggregate In Concrete: Use Of Industrial, Construction, And Demolition Waste". Springer Science \& Business Media. 2012. ISBN 978-1-4471-4540-0.

[5] G. Pachideh, and M. Gholhaki. "An Experimental Study On The Performance Of Fine-Grained Concrete Incorporating Recycled Steel Spring Exposed To Acidic Conditions". Advances in Structural Engineering. 2020. p.1369433220915794.

[6] S. Pantawee., T. Sinsiri., C. Jaturapitakkul, and P. Chindaprasirt. "Utilization Of Hemp Concrete Using Hemp Shiv As Coarse Aggregate With Aluminium Sulfate [Al2 (SO4) 3] and Hydrated Lime [Ca (OH) 2] Treatment". Construction and Building Materials, 156. 2017. pp.435-442.

[7] M.B. Leite, and V.M. Santana. "Evaluation Of An Experimental Mix Proportion Study And Production Of Concrete Using Fine Recycled Aggregate". Journal of Building Engineering, 21. 2019. pp.243-253.

[8] B. Pacewska, and I. Wilińska. "Usage Of Supplementary Cementitious Materials: Advantages And Limitations". Journal of Thermal Analysis and Calorimetry, 142(1), 2020. pp.371-393.

[9] B.W. Yifru, and B.B. Mitikie. "Partial Replacement Of Sand With Marble Waste And Scoria for Normal Strength Concrete Production". SN Applied Sciences, 2(12), 2020. pp.1-11.

[10] P. Górak., P. Postawa., L.N. Trusilewicz, and A. Łagosz., 2021. "Lightweight PET Based Composite Aggregates In Portland 
Cement Materials-Microstructure And Physicochemical Performance". Journal of Building Engineering, 34, 2020. p.101882.

[11] Y.W. Shewalul. "Experimental Study Of The Effect Of Waste Steel Scrap As Reinforcing Material On The Mechanical Properties Of Concrete". Case Studies in Construction Materials, 2021. p.e00490.

[12] M.J. McGinnis , M. Davis., de la Rosa, A., Weldon, B.D, and Y.C Kurama." Strength And Stiffness Of Concrete With Recycled Concrete Aggregates". Construction and Building Materials, 154, 2017. pp.258-269.

[13] H. Zhang, and Z.G. Wen. "The Consumption And Recycling Collection System Of PET Bottles: A Case Study Of Beijing, China". Waste Management, 34(6), 20.14. pp.987-998.

[14] A.D. Gashahun. "Investigating Sand Quality Effect On Concrete Strength: A Case Of Debre Markos And Its Vicinities". International Journal of Construction Management, 2020. pp.1-9.

[15] O.I. Nkwachukwu., C.H. Chima., A.O. Ikenna, and L. Albert. "Focus On Potential Environmental Issues In The Plastic World Towards Sustainable Plastic Recycling In Developing Countries". International Journal of Industrial Chemistry, 4(1), 2013. p.34.

[16] R. Siddique., J. Khatib, and I. Kaur. "Use of recycled plastic in concrete": A review. Waste Management, 28(10), 2008. pp.18351852.

[17] V. Sinha., M.R. Patel, and J.V. Patel. "PET Waste Management By Chemical Recycling: A Review". Journal of Polymers and the Environment, 18(1), 2010. pp.8-25.

[18] G. Pachideh., M. Gholhaki, and H. Ketabdari. "Effect Of Pozzolanic Wastes On Mechanical Properties, Durability And Microstructure of The Cementitious Mortars". Journal of Building Engineering, 29, 2020. p.101178.
[19] R. Siddique, and M.I. Khan. Supplementary cementing materials.Springer Science \& Business Media. 2011.

[20] M. N. Soutsos., T.T. Le, and A.P. Lampropoulos. "Flexural Performance Of Fiber-Reinforced Concrete Made With Steel And Synthetic Fibers". Construction and building materials, 36, 2017. pp.704-710. 